\title{
Adopting consumer time: potential issues for higher education
}

\author{
Paul Gibbs*
}

Institute for Work Based Learning, Middlesex University, London, UK

\begin{abstract}
Time and temporality have received little attention in the consumerism, marketing or, until recently, higher education literature. This paper attempts to compare the notions of timing implicit in education as paideia (transitional personal growth) with that implicit in consumerism and the marketing practices which foster it. This investigation uses Heidegger's three notions of being and their corresponding concepts of time to understand the phenomena of education and consumerism. It suggests that the consumerist notion of time can changes what higher education might be through how individuals understand their being. In my conceptual discussion I challenge higher education to resist its being temporalized by consumerism.
\end{abstract}

Keywords: consumerism; higher education; marketing; time; Heidegger

\section{Introduction}

It is precisely this reduction of education to the instrumental, ... that is the source of everything awry with the university today. (Heidegger 2002, 35)

According to Bjuremark (2007), reforms in higher education may be understood as a challenge to the broad, historical sense of academic work. Higher education is exposed to competition in marketplace conditions where institutions are compelled to compare their offerings with others to attract consumers. Naidoo and Jamieson see these consumerist forces, driven in the UK by tuition fees, quality assurance, managerialism and the student-consumer paradigm, as reducing the power of the academic to 'define the curriculum, determine acceptable standards of student achievement and decide appropriate pedagogic strategies' $(2005,268)$.

My discussion is set against increasing corporate, consumerist and government inroads into the realm of education and demanding that 'education serve the dictates of the marketplace and its demand for economic growth, [and] through the inroads of advertising and marketing' (Norris 2006, 459-60). This creates what Young (2002) considers to be the bureaucratic and machine-like modern university in which it is no longer customary to find teachers and students but 'suppliers' and 'consumers', with all that this entails. More specifically it nurtures an ideology of consumerism where the meaning of life is to be found in the buying of things and pre-packaged experiences. Further, it allows people to create a personal identity and value system through what they consume. For academics and for students this may create anxiety and alienation over what they take students to be and what they take themselves to be. In this unthinking packing of activities in time, what is lost is the time to think.

These changes are having an impact on the very nature of education through changes in students' and academics' pace of work and their time perspectives of the form of education that institutions deliver. For example, Guthrie and Neuman (2007) suggest that traditional collegiate, academic decision-making methods are being threatened as the university becomes more

\footnotetext{
*Email: P.Gibbs@mdx.ac.uk
} 
responsive to the needs of the consumer. Barnett (2007) has suggested that for students and academics alike there has been a transition from a time when both past and future were experiences within the being of the present, to one where temporality has become disintegrated and a linear sense of time predominates.

In this paper I use a Heideggerian perspective on time to help understand the challenges faced by higher education institutions and their seemingly irresolute adoption of the tempo and rhythm of the world of the consumer. I will suggest that in doing so they endanger any mission they may have to educate its community to press ahead with the possibilities of what they might themselves determine to become. In doing so, I assume that a central tool for the perpetuation of consumerism is marketing. Such an assertion is supported by, for example, Bourdieu (1984), Featherstone (1991) and, most recently, marketing scholars such as Abela (2006), who claims that the rise of consumerism parallels the rise of modern marketing.

I first discuss Heidegger's complex ideas on time and then compare them to the characteristics of education and consumerism. Finally, I ask questions concerning the effect of the totalizing of the time of consumerism on the essence of higher education.

\section{Heidegger and time}

Heidegger's approach to time is complex and as in all his work he tends to invent his own vocabulary. For our purposes this means three different categories of time and being. At the centre of Heidegger's understanding of being is the rejection of a singular idea of being, and the suggestion that it can take one of three forms. Each has associated with it a specific notion of time.

The first and most primordial form of being is 'Dasein', the being of us. For Heidegger, the 'essence of Dasein lies in its existence' $(1962,67)$. We understand ourselves by a taking a stance on who we are and who we can be. The mode of time of 'Dasein' is originary' temporality. Originary temporality is not the sequentialism that we commonly associate with temporality, where the future succeeds the present, which in turn succeeds the past. It is, as Blattner explains, 'a temporal manifold that can be present in any given moment of sequential time' $(1999,92)$. The concept of sequential temporality - past, present and future - is derived from the manifold in originary time; the time of reckoning and of the universe.

Originary temporality contains notions of the past and future integrated within the present. They are made known through horizons and are never brought actually into the present. This is because the future is not a latter-day now and the past is not an 'earlier than' now; they are not of our common understanding where the future is attained and recedes into the past. Moreover, the originary past is that which is already there. It is what we are attuned to, not a personal past which has been but a past, already gone when I encounter it. Heidegger proposes that every temporal state temporalizes itself as a whole and argues that:

Temporalizing does not signify that ecstasies came in succession, the future is not later than having been, and having been is not earlier than the present. Temporality temporalizes itself as a future which makes present in the process of having been. $(1962,40 I)$

Thus, originary temporality is existence in the meaning of 'Dasein' making sense of itself. For instance, I can take on the role of a professor but the existential becoming of a professor is always futural; something to become. I can act in ways that are 'for-the sake-of' becoming a professor and be called a professor, but I can never reach what it is like to become a professor. This is a strange notion, but one we recognize in our everyday dealings with people. For example, people sometimes obviously overstate what they are, in place of what they want to be. They may disguise their true identity, but are often 'outted' as frauds as their actions show them not to have the skills required of such a position. This is the existential notion of being that I propose ought to be fostered by higher educational institutions. It will not require the denial of other 
forms of being and times but will seek to use them purposefully as Dasein takes a stand on what it might be. I have called this mode I time.

The second form of being is that of equipment, which gains its meaning from its cultural significance. The basis of its being is in its 'in-order-to' use in our practices; they are a means to an end. They form referential totalities such as an office, bedroom, lecture theatre or sports stadium which help us define ourselves within those worlds. The absence or malfunction of this equipment may cause us anxiety about our location or skills. For instance, with no whiteboard, chairs, PowerPoint or students, the room barely signifies to us that we are lecturers, in a lecture theatre, ready to start lecturing. Equipment is 'ready-to-hand' and its mode of time is worldtime; a world that is signified by equipment. It is the equipmental structure of our environment that bestows its familiarity and allows us to understand what practices are appropriate and acceptable in this world.

Our everyday practices are performed and are deemed appropriate in worlds, for example the world of work or the world of the family. For here we tend not to take a stand on what we might be (that is Heidegger's notion of authenticity) but allow ourselves to be carried along with what others may want us to be; we fit in, we are accepted and find comfort in being just one of the crowd. Heidegger calls these worlds 'worldhoods' to distinguish them from the universe, and through them we begin to realize what we might be. These worlds' significance and meaning is derived from our practices and the use of equipment. The time that structures these worlds is a time that enables us to understand ourselves within that world and go about our social lives. Heidegger refers to it as 'datable time' in which entities have duration - a time span - and their temporal relationship defines the temporal structure of world time.

The 'now', the 'then', and the 'on that former occasion' thus have a seemingly obvious relational structure which we call 'datability' [Dateierbarkeit]. Whether this dating is factically done with respect to a 'date' on the calendar must still be completed disregarded. Even without 'dates' of this sort, the 'now', the 'then' and the 'on the former occasion' have been dated more or less definitively. $(1962,459)$

The infrastructure of datable time is populated by the times to do something: to work, to play, to lecture and to have lunch. It is experienced differently depending on the circumstances of their occurrence, they are experienced and remembered in mode 2 time, we temporalize ourselves by giving time for what the situation demands, whereas in mode 3 everything has a time when it happens.

The significances of these times are understood through their public-ness. This aspect of our being is manifest in social acts of being with others, through which others can understand the same significances as ourselves. The temporal present - the now - provides the context in which this time is located and allows a succession of presents which is our common understanding of temporality; a past, a future and a present. For Heidegger, it is the time which turns out to be the kind of time in which the ready-at-hand (equipment identified as ready to use in order to do something) and the present-to-hand (objects whose function is not relevant to the way in whichthe-world is encountered) are revealed. This 'requires that these entities which are not of the character of Dasein shall be called entities within-time' (Heidegger 1962, 465). Blattner summarizes this everyday experience of time as:

The Now that spans from the formerly (the Earlier) to the then (Later on), which is dated by some event or activity in the world, which is significant in that it is appropriate or inappropriate for action, and which is public, accessible to all. $(1999,134)$

I have called this mode 2 time.

The third form of being is that of independent objects with characteristics which distinguish them and remain with them such as stones, trees or stars. They are present-at-hand and 
understood through inspection, for instance scientific inquiry. They have a mode of time that is called 'ordinary time'. The time of the universe is appropriated by Heidegger to give a social dimension to the durability and datability of world time, described above. As previously suggested, this ordinary, mode 3 time is derived from ordinary temporality. It is manifest within 'the horizon of concern with time which we know as astronomical and calendrical timereckoning' (1962, 455).

We use it to reckon how we can describe the world of entities; it is abstract and successive; it is clock and calendar time. It is time in which the equipment and entities are encountered within time. Yet, as Heidegger describes, this temporal notion of time is not our ordinary understanding of time. This time levels off and covers up the temporality and shows itself as a sequences of 'nows' which are constantly 'present-at-hand', 2 simultaneously passing away and coming along. Time is understood as a succession, as a 'flowing stream' of 'nows', as the course of time $(1962,474)$.

In this sense, our everyday existence as 'Dasein' is determined by our realization of our originary temporality (mode I time) as presented through our everyday practices. If we hide our own temporality and live in the present, we become averaged. That is, we accept the tranquillity of others as our norm. Such tranquillity is encouraged in a world where everything and everybody exists to become the equipment of others and to become consumers for the sake of consumption, rather than to take a stand on their own temporality and to understand their possibilities for themselves. This I refer to as mode 3 time.

This third mode of time, world time, clock time, is the world of consumerism, where we use up time to secure the benefits we desire to be at home, unquestioningly as any other within our consumer societies. In educational terms, time is an obstacle to be overcome so more consumption can take place. This requires shorter courses, the rejection of un-assessed work (for time is wasted in lingering), immediate feedback and precisely defined clusters of knowledge to be identified and consumed. There is no time to become only time to be what we have consumed.

In summary, for Heidegger, there are three modes of being, each associated with a distinct notion of time. By temporalizing being, Heidegger offers a basis for understanding how practices engage us with our worlds. Moreover, should we fail to recognize these differences and confuse their temporal forms, we run the risk of saying that temporality is something which is:

... 'earlier' and 'later', 'not yet' and 'no longer'. Care ${ }^{3}$ would then be conceived as an entity which occurs and runs its course 'in time'. The Being of an entity having the character of Dasein would become something present-at-hand. (1962, 375)

Thus Heidegger allows us to conclude that if the temporality of being becomes that of the present-at-hand our being as Dasein is violated.

Table I summarizes these concepts.

Table I. Heidegger notions of time and being.

Time Related form of Being

Originary or primordial time - mode I time

Dasein, structure through care as: existentiality (future), Facticity (past) and falling (present)

Datable time, that is events located in relation to others. It is the shaping of separated notions of past, present and future - mode 2 time

Time reckoning or clock measured linear time - mode 3 time

Ready-to-hand and un-ready-to hand (the state where equipment, including language, does not function as expected. Such occurrences may lead to a present-athand mode of being, to investigate the problem)

Present-at-hand, calculative time 
The difference between ordinary (mode 3 time), the abstract measurement of the flow of time and mode 2 is that mode 2 is relational to the events themselves based on their temporal significances, whereas mode 3 is an external linear time within which the events can be externally measured. For instance, the great lecture is remembered as preceding the disappointment of the final exam result (mode 2) and not that it occurred at 9.33 am on 31 December 2007 (mode 3). We coordinate in abstract mode 3 time.

Indeed all three modes of time are bound together degeneratively and dependently; ordinary time is a degenerative form of world time, and world time a degenerative from of originary temporality. Thus, the distinctive existential meaning of our being that is our originary temporality is levelled off. In allowing this, we have an option to resist and so are culpable if we don't. We risk losing our essential being and become no more than resources to be packaged and consumed; that is our being ceases to be Dasein and we adopt the being of ready-to or presentat-hand entities.

In the face of this, educational institutions are presented with a gigantic challenge to enable them to understand themselves and then foster the integrated notion of originary temporality if they see as their mission the development of humanistic values in addition to more practical ways of earning a living. ${ }^{4}$ This requires them to encourage all their stakeholders - students, faculty, donors of funds - to be open to their world and not to encourage thought-less responding to the needs of others and in turn treating others and themselves as reservoirs of resource. Our individual historicality and our future possibilities need to be disclosed so that Dasein might truthfully take a stand on itself and our formal education ought, amongst its other functions, to facilitate this. It will require encouraging a stringency and resoluteness in educational instututions' activities through which they reveal the importance to our being of the originary future. In so doing they need to disclose a way of being in the present which is not the generalized way being of others which, I perceive, they currently do through notions such as performativity. I am looking towards the university to revitalize primordial temporality. If education institutions do not take up the challenge, but dwell in the tranquility of external directives, always ready-tohand to shape a mode 2 or 3 future, they contribute to the nihilism currently manifest in consumerism and it becomes evermore inevitable.

\section{Consumerism and the changing notion of time}

We understand at a primordial level that our being has a context, or background - like the ether of physics - which contextualizes our actions. Its presence allows things to show up with contextual significance in how they present themselves and in how we react to them. We understand this background through what Heidegger calls 'circumspection', and through this circumspection we are oriented to the presence of what is of concern. The shaping of this circumspective orientation is socially derived, and forms the environment of our everyday experience. Ideology, faith and other causes try to shape our way of seeing things.

Heidegger does talk about how the "circularity of consumption for the sake of consumption is the sole procedure which distinctively characterizes the history of a world which has become an unworld' (1973, 107). However, the worldhood of consumerism is subsumed in his later works where he sees technology as totalizing our practices and potentially our being. His solution is to understand how this occurs and to find ways of living with technology without taking on a technological way of being (see Dreyfus and Spinosa 2003). For instance, he says that technology is no mere means but that it:

$\ldots$ is a way of revealing; a way of seeing the true meaning of an entity. If we give heed to this, then another whole realm of the essence of technology will open itself to us. It is the realm of revealing, i.e., of truth. (1977: 12) 
Moreover, Heidegger argues that we need to be struck by the strangeness of this statement and be drawn to understand what technology means. I will borrow his way of thinking but revert to Heidegger's initial concern with consumerism. How can we live within a consumerist society without being restricted in our openness to people and things? It is in this sense of its education's revealing purpose that $\mathrm{I}$ intend for us likewise to be struck by the consumerism now implicit in our higher educational system.

The difficulty is where the background against which meaning of a thing is demonstrated becomes uniform and diversity of personal histories are lost. If the background is one of consumerism, then things will emerge and gain their meaning in this context. To reinforce and sustain the background of consumerism, marketing management shapes the significance of our world.

Marketing is a grasping of the needs of consumers. It provides the structure for the development and promotion to consumers of products and services to perpetuate consumerism. Thus marketing provides both a hermeneutic to understand consumerism and a way of shaping it. Moreover, implicit in marketing is exchange, a process that Arjaujo (1999) points out requires a notion of past, present and future which is both relational and measurable. It is mode 2 and 3 time, leaving little room for mode I time - the time of Dasein.

This gives a common, circumspective meaning to equipment's function of encouraging the practices of consumerism and identification of entities as commodities and consumers. As I have already indicated, if our worldview becomes one of things whose purpose is to be consumed, the very nature of their being and time is challenged and levelled down as Heidegger has suggested to a single dominant form of time, mode 3 time.

This provides the context for the everyday datability of events to change their relative pace, their rhythm and their expected duration. It allows a measure to judge the accelerated rate at which these events are sequentially located, bringing the future to us faster, allowing us to linger less in the present and requiring us rapidly to forget entities in the past. The increased density of our present takes away our time to act from our originary temporality of our authentic being (mode I time) and replaces it with the reckoning of ordinary time (mode 3 time) of a successive future, present and past.

In our everyday mode of being we get swept up, irresolutely, in this flow and understand ourselves in terms of these encounters which are thrust upon us. We busily lose ourselves in dealing with the rapidly changing events that concern us. This leads us in a certain way of talking: 'I have no time' $(1962,463)$. The time Heidegger means here is the notion of primordial temporality, lost to mode 3, ordinary time. This may be willingly accepted in order to make sense of a world in our everydayness, but such an acceptance must be informed by its alternatives. This is a role education can play, awakening us to the possibility that we can take a stand against accepting the role 'for-the-sake-of' acquisition of commodities that can often, unquestioned, define our everyday practices.

\section{Higher education's mission}

Of course, this ought to be impossible as it would mean that the being of 'Dasein' would change and no longer be 'Dasein', at least authentically, and we would be no more than equipment or things ready-to-hand for others to use as suggested by Heidegger. Is this what consumerism is doing, pressing us to turn away from knowing ourselves by taking a stance on ourselves and accepting the being of another consumer entity? Furthermore, if education embraces consumerism, whose 'for-the-sake of which' is immediate consumption, will it level down the potential for us to develop our own authentic Dasein with the help of higher education institutions? If it does not resist consumerism by developing our authentic being through its ordinary temporality, 
we need to question whether institutions are offering a distinctive mission of challenging society or whether they are just delivering consumer ideology and practice. This interpretation is very important, for our being is constituted as primordial temporality and is evident by our practices. If we act as consumers in the world of consumer time, what does it make of our being? Does it lead to the commodification of being, in such a way that it risks ceasing to be 'Dasein'?

Heidegger sheds some light on the effects of choosing to live through world time (mode 3 ) rather than originary temporality (mode I).

The Being of Dasein is care... Dasein awaits its potentially-for Being-in-the-world; it awaits it in such a manner that it 'reckons' on and the 'reckons' with whatever has an involvement with for the sake of this potentiality-for-Being - an involvement which, in the end, is a distinctive one. $(1962,465)$

Thus, Heidegger warns us that in the everydayness we need to be circumspect in how we are to concern ourselves with our activities. ${ }^{5}$ We might take this warning to be aware of the dangers of being too concerned with entities and identifying too closely with them.

The practices of consumerist time are already evident in a higher education context. For example, Ylijoki and Mäntylä (2003) suggest that there is a reduction of 'timeless time' (time not controlled by external constraints; time for reflective thought) and an increase in 'scheduled time' with its external imposition and accelerating pace. Clegg (2003), Ylijoki and Mäntylä (2003) and Ylijoki (2004) claim it affects research by accelerating the pace of work; decreasing autonomy over time management; causing a higher proportion of work on short-term projects; and increasing time pressures.

In short, the complex originary temporality of our authentic being flourishes in an educational system that resists and questions the temporality of consumerism. It confronts the comfortable and secure world created for us through consumerism's letting us forget our responsibility to ourselves to accept the choices we make and letting us forget the past we have been given. In this consumerist world, the responsibility for our own future possibilities and attunement to our past is covered over in the present desire to own and to have. We forgo our responsibility and control by allowing ourselves to be forced to 'fit in'. We forget, or are persuaded by advertising to ignore what Heidegger takes as our existence: '(as) an entity which has to be as it is and as it can be' $(1962,276)$.

Universities that promote education as a commodity by offering hedonistic gratification and routes to careers position education as one more thing to be consumed. Klassen (2000) reports, for example, that in the marketing of higher education institutional values and priorities are usually symbolized by the message 'that students will not need to change in order to be successful' $(2000,21)$. Even more disturbingly, he concludes that for the students in half his sample, 'the perspective of college life offered is practically devoid of commitment and loyalty to anything beyond having a good time while waiting to graduate'. The impact of these changes is summarized by Hassan, who observes:

... the commercialization of the university is primarily an economic and political process of transformation that has little if anything to do with education, knowledge production and the well being of either staff or students. What is more, these changes are all being refracted through the prism of neo-liberal ideology. $(2003,77)$

How might we resist a contemporary focus on instrumentality and restore a notion of time for both thought and thoughtfulness in our students? To use the terminology of Giroux and Giroux (2004), how do we restore the public time gifted for the use of the university for thinking, reflection and critical appraisal of society, its knowledge and its moral positioning? As they insightfully reflect, time 'refers not only to the way in which temporality is mediated differently by institutions, administrators, faculty and students, but also how it shapes and allocates power, identities, and space through a particular set of codes and interests' $(2004,226)$. This is an ontological 
approach and more like the education suggested by Barnett (2007). It has not the linearity of production, but a grasping of meaning in terms of temporality. The difference is that, instead of the being as present-at-hand in mode 2 and 3 time, it is being that can project its own possibility as in mode I time. This is not to suggest that there is not a place for activities framed in mode 2 and 3 time. I recognize that we need for much of our everyday experience to hold entities up to scrutiny and critical appraisal; we don't just carry on living with them in a non-observational way but I am arguing that neither must we allow this to be the only way in which we exist.

\section{Heidegger once again}

How might Heidegger enable us to understand the originary temporality of education that I am attempting to preserve? Education may be understood as the way in which we learn to take a stand on our being and the way we act in terms of and in relation to other entities. Heidegger explicitly states that:

To learn means to make everything we do answer to whatever essentials address themselves to us at the given time. Depending on the kind of essentials, depending on the realm from which they address us, the answer and with it the kind of learning differs. $(1968,14)$

This is achieved through a relatedness to what we engage in and is lost when we are distanced from it. Again, Heidegger claims that without this relatedness we become 'determined exclusively by business concerns' $(1968,15)$. His example is that of a cabinetmaker's apprentice, but he extends his point to include poetry and thinking. Moreover, he claims that the prevention of such an orientation depends on the presence of a teacher whose primarily role is to let the student learn, specifically about learning. This requires flexibility in approach to things whether encountered as entities, or as equipment within a referential whole. Moreover, equipment encountered outside such a frame of reference can become entities stripped of purpose. We deliberately do this when we engage in scientific enquiry, when the equipment which is used for the sake of achieving a goal malfunctions, or we are not skilful at using it.

This last situation brings forth what some, Dreyfus for instance, refer to as another mode of being whereas others see it as a mid-state between present-at-hand and ready-to-hand; the 'unready-to-hand' of equipment. This mode is when what we are doing 'in-order-to' achieve ceases to be in the background, but becomes conspicuous rather than being absorbed in the practical activity. It happens when we have to think how to do something, such as remembering a long-lost formula, take up the piano again or perhaps learn a new language. We do this 'inorder-to' make us more familiar with the experience of a new world, so as to understand the significant events and their world relational timings. For example, when approaching a person in another country and asking them a question, we expect them to understand and respond accordingly. When what we expect to happen does not and our first language is found wanting, we try something else. We might explore what else we know to do in a similar circumstance aboard; seek a common language, make signs, or shout. We may deliberate about how best to resolve the problem and develop a schema for resolving it - finding an interpreter - or perhaps just stand there helplessly before eventually retreating to somewhere more familiar to prepare ourselves better for the future.

How we respond depends on how we encountered the problem: authentically or inauthentically. Heidegger suggests that our understanding of such events is:

... grounded primarily in the future (whether in anticipation or in awaiting). States-of-mind temporalize themselves primarily in having been (whether in repetition or in having forgotten). Falling [our everyday-ness] has its temporal roots primarily in the Present (whether in making-present or in the moment of vision). (1962, 40I) 
If we approach the language problem inauthentically, we use only the language skills we have at the time to shout and so on, getting louder as our time is spent, for we have other things to do, and we wait impatiently to see what will come of our efforts. It matters little if we get what we desire, as we leave the situation blaming the other for not speaking our language and soon forget what contributed to the lack of understanding - our own lack of competence. However, if we approach the situation authentically, we experience what Heidegger calls a 'moment of vision' - that is, when we experience the event through the present of our originary temporality (mode I time) and not that of world time(mode 3). Then we may come to understand that our lack of language skills, or the pressure we were putting on the other person, may have contributed to the lack of communication. We may recall when this has happened before and then feel guilty about it happening again. We may then anticipate it not happening again by resolving to do something about it, by taking previously neglected language lessons.

In the above example, I am not expressing a view that taking for granted that those we meet will speak our language is necessarily blameworthy on all occasions, for we need to take much for granted in our everyday lives if they are to run smoothly. I simply want to suggest that education can make us aware of different ways of responding to a problem and its solution rather than seeing it as a present-at-hand issue able to be resolved in mode 3 time. Heidegger grasps these types of problem as ones where we do not have sufficient mastery of skills in order to act appropriately in certain circumstances. Having more than the instrumental skills inorder to speak a language is ontological in the sense of seeking to become a good communicator 'for the sake-of' which we gain our position in civil society.

Heidegger sees the role of education as concerned with the 'very foundation of our being as human' $(2007,167)$. This education is Plato's paideia, and Heidegger states that 'real education lays hold of the soul itself and transforms it in its entity by first of all leading us to the place of our essential being and accustoming us to it' (2007, 167). For Heidegger, our existential being is found in our originary temporality through which we face the truth of our existence. In this sense, education is ontological and requires us to examine what we have come to know as true in the shaping of our being. We do this by ridding ourselves of old views, seen with an habitual eye, and 'look at things most sharply, just as it now does the things it is presently turned toward' (Republic 1997, 519b). This turning is central to an understanding of education as truth-revealing, and as the coupling that Heidegger makes in his analysis of Plato's Cave.

Unlike Plato, however, for Heidegger the proper dimension of the allegory is that it:

... recounts a series of movement rather than just reporting dwelling place and conditions of people inside and outside the cave. In fact, the movements that it recounts are movements of passage out of the cave into daylight and then back out of daylight into the cave. $(2007,165)$

The notion of the interpreted temporality of being is exposed in this quotation. The movement which Heidegger describes as the move to understanding and changing the way one comports to the concealed, in a progressive unconcealing in search of truth and understanding of being, may also be interpreted as the realization of the temporality of Dasein. The movement is from one's past - chained and restricted; unchangeable - to the realization of a confused present of the manmade form of illumination on the world; the fire. The temporality of consumerism is the temporality of the revealed present, where the dark shadows of the cave are illuminated by flickering light from a fire which offers an increased awareness but only by permitting a specific temporal notion; the present.

\section{Concluding discussion}

I have tried to suggest that consumption and transformative education within higher education institutions have, and ought to have, different temporal realities. Moreover, if consumption's 
time, the time of reckoning, becomes the process which shapes the temporality of our educational goals rather than the originary temporality of taking a stand on what we want to be, educational institutions cease to add significance to our world. The danger is that it replaces our notions of education as a means to think of a future of imagination, hope and opportunities not yet known, with sequential and knowable 'nows' - a view of education based on our being in the world of consumption.

Further, I have suggested that universities embracing consumerism ought to create a dilemma for the university leadership: what are they seeking to achieve and why? The purpose of marketing is to achieve predetermined ends through the application of marketing skills and technologies. It has explicit goals - market share, sales volumes or profit, and an implicit desire to trap the consumer in their present 'in-order-to' buy - but at what cost? Naidoo and Jamieson have indicated that, under a consumer notion of entitlement, a student disposition 'may have negative ramifications for the development of higher order skills and, more importantly, the dispositions and attitudes required for autonomous, lifelong learning' (2005, 273).

For Heidegger, in such a world 'the human is challenged forth to comport himself in correspondence with the exploitation and consumption: the relation to exploitation and consumption requires the human to be in this relationship' $(2003,63)$. Is this what education ought to be about? Or is it inevitable in these times of consumerism? Not according to Barnett (2007), who offers a distinctive notion of education which needs its own time and is identified by him as 'pedagogical time' $(2007,53)$, a time for ontological change. It is defined by a time during which the institution can foster the willingness of students to 'venture forth' into the unknowable future beyond their studies with the confidence and trust nurtured in the academy to face the uncertainty of the future. It creates the time for the student to become, through the experience of higher education. In so doing the student becomes able to confront the anxiety of the future with confidence, creativity and criticality. It does not achieve this by describing the unknowable as some form of predictable, yet inauthentic, anxiety-free extension of the present. Moreover, Barnett (2007) recognizes the tension between this pedagogical time and the market's notion of consumable linear time, arguing that the market relationship 'jostles with and even threatens to crowd out the pedagogical relationship' $(2007,9)$.

Finally, rather than rendering themselves up to the consumerism embedded in marketing, higher education institutions should attempt to promote a community where individuals seek to reclaim their originary temporalities through trust and meaningful engagement with their world. In the crowded world of skills, training and education providers, what would perhaps ironically give some universities 'a competitive edge' is to resist the tools and the consequences of consumerism. If higher education institutions continue to follow traditional consumerist practices they will replace worthy education, as a facilitator of human experience, endeavour and imagination, with educational propaganda and consumption.

Marketing ought to be one of the concerns of higher education as it faces consumerism and I have attempted to illustrate this in terms of time and being. This is not an argument to bar the virtues of education from all those willing to benefit: quite the opposite. We need to increase the expansion and penetration of higher education provision but not a consumerist education. We need marketers who are educationalists with understanding and belief in the value of education to promote it, even in the face of financial pressure from those who would turn the worth of education into a valuable, consumable commodity.

\section{Acknowledgements}

I grateful for the comments of the reviewers on an earlier draft of this paper and especially for the considerable help provided by the Editor. 


\section{Notes}

I. According to Kisiel, in his 1992 translation of Heidegger's History of the concept of time, the translation of 'ursprüngliches' can equally be 'primordial' or 'originary'. I will use them as substitutes, making the choice on the basis of what seemingly suits best.

2. Heidegger contrasts the readiness-to-hand of equipment with the presence-at-hand of mere things.

3. The structure of Dasein (added to quote).

4. I am reminded here of Buber's characterization of educative relationships as 'in order to help the realization of the best potentialities in the pupil's life, the teacher must really mean him as the definite person he is in his potentialities and his actuality; more precisely, he must not know him as the sum of qualities, strivings and inhibitions, he must be aware of him as a whole being and affirm him in his wholeness' $(1959,131)$.

5. In the 1962 translation of Being and time by Macquirrie and Robinson, 'Besorgen' is translated as 'concern', but in the sense that we concern ourselves with 'activities we perform or things which we procure' $(1962,83)$.

\section{Notes on contributor}

Paul Gibbs is Reader in the Institute of Work Based Learning at Middlesex University and is interested in the nature of being as shown through work, marketing and education.

\section{References}

Abela, A.V. 2006. Marketing and consumption: A response to O'Shaughnessy and O'Shaughnessy. European Journal of Marketing 40, no. I-2: 5-16.

Araujo, L. 1999. Exchange, institutions and time. In Rethinking marketing: Towards critical marketing accounts, ed. D. Brownlie, M. Saren, R. Wensley, and R. Whittington, 84-105. London: Sage Publications.

Barnett, R. 2007. A will to learn: Being a student in an age of uncertainty. Buckingham: Society for Research into Higher Education.

Bjuremark, A. 2007. Flexible figures in discourse of university governing: A work-in-progress report. Paper presented at Fifth international conference on researching work and learning, December 2-5, in Cape Town, South Africa.

Blattner, W. 1999. Heidegger's temporal idealism. Cambridge: Cambridge University Press.

Bourdieu, P. 1984. Distinction: A social critique of the judgement of taste. London: Routledge.

Buber, M. 1959. I and thou. Edinburgh: T and T Clark

Clegg, S. 2003. Learning and teaching policies in higher education: Mediations and contradictions of practice. British Educational Research Journal 29, no. 6: 803-19.

Dreyfus, H.L., and C. Spinosa. 2003. Further reflections on Heidegger, technology, and the everyday. Bulletin of Science Technology Society 23: 339.

Featherstone, M. 1991. Consumer culture and postmodernism. Beverley Hills, CA: Sage Publications.

Giroux, H., and S. Giroux. 2004. Take back higher education. New York: Palgrave Macmillan.

Guthrie, J., and R. Neumann. 2007. Economic and non-financial performance indicators in universities. Public Management Review 9, no. 2: 231-52.

Hassan, R. 2003. The chronoscopic society: Globalization, time and knowledge in the network economy. New York: Peter Lang.

Heidegger, M. 1962. Being and time. Trans. J. Macquirrie and E. Robinson. Oxford: Blackwell.

Heidegger, M. 1968. What is called thinking. Trans. J.G. Gray. New York: Harper Row.

Heidegger, M. 1973. Overcoming metaphysics. In The end of philosophy. Trans. J. Stambaugh. New York: Harper \& Row.

Heidegger, M. 1977. The question concerning technology. In Basic writing. Trans. D.F. Krell, 307-42. London: Routledge.

Heidegger, M. 1992. History of the concept of time. Trans. T. Kisiel. Bloomington: Indiana University Press.

Heidegger, M. 2002. The age of the world picture. In Off the beaten track, ed. J. Young, and K. Haynes. Cambridge: Cambridge University Press.

Heidegger, M. 2003. Four seminars. Trans. A. Mitchell, and F. Raffoul. Bloomington: Indiana University Press.

Heidegger, M. 2007. Plato's doctrine of truth. Trans. T. Sheehan. In Pathmarks (texts in German philosophy), ed. W. McNeill. Cambridge: Cambridge University Press. 


\section{P. Gibbs}

Klassen, M.L. 2000. Lots of fun, not much work, and no hassles: Marketing images of higher education. Journal of Marketing for Higher Education 10, no. 2: II-26.

Naidoo, R., and I. Jamieson. 2005. Empowering participants or corroding learning? Towards a research agenda on the impact of student consumerism in higher education. Journal of Education Policy 20, no. 3: 267-8I.

Norris, T. 2006. Hannah Arendt and Jean Baudrillard: Pedagogy in the consumer society. Studies in Philosophy and Education 24: 457-477.

Plato. 1997. The complete works. Ed. J.M. Copper. Indianapolis: Hackett Publishing Group.

Ylijoki, O.-H. 2004. Orientations of future in academic work. Paper presented at the 20th EGOS Colloquium The Organization as a Set of Dynamic Relationships, Sub-theme 22, July I-3, Ljubljana University, Slovenia, http://www.uta.fi/tasti/papereita/ylijoki_egos04_paper.pdf.

Ylijoki, O.-H., and H. Mäntylä. 2003. Conflicting time perspectives in academic work. Time and Society I2, no. I: 55-78.

Young, J. 2002. Heidegger's later philosophy. Cambridge: Cambridge University Press. 